\title{
To Save Lives: The Ethical Precedent set by South Africa's Leadership during Lockdown
}

\author{
David Anthony Pittaway \\ https://orcid.org/0000-0003-2342-0721 \\ The Institute for Coastal and Marine Research \\ Nelson Mandela University \\ pittaway@gmail.com
}

\section{Abstract}

None of the lockdown decisions made by governments in response to the Covid19 pandemic can be considered to be self-evident outcomes of objective data. Executive members of each nation's government considered the particular pandemic circumstances that they deemed to be important and relevant, and decisions were made based on limited epidemiological data in combination with a variety of contingent socio-political and economic variables. These kinds of decisions fall partly into the philosophical category of ethics, and they can be summarised under the umbrella question: What should we do? The precautionary principle must have played a large role in the decision-making process, considering the conspicuous lack of reliable data on which to base decisions. In this article, I turn to South Africa as a case study, and I tease out some of the precautionary factors that may have, in part, driven many major decisions prior to and during the South African lockdown. I argue that if the precautionary principle can be used as part of the justification for large-scale government interventions to save an unknown number of lives, then consistent use of the principle should warrant concerted responses by government to a variety of potential threats and problems in South Africa. I also argue that for government's focus on saving lives to be consistent, preventative action in response to phenomena that take worryingly large numbers of lives annually, is necessary.

Keywords: precautionary principle; prevention; Covid-19 lockdowns; consistency; pandemic

\section{UNISA $\approx$}




\section{Introduction: Background and Context}

On March 3, 2020, the Director General of the World Health Organisation (WHO), Tedros Adhanom Ghebreyesus, delivered a speech to international audiences in which he stated the following: "Globally, about 3.4\% of reported Covid-19 cases have died. By comparison, seasonal flu generally kills far fewer than $1 \%$ of those infected" (WHO 2020). Ghebreyesus's announcement of a 3.4\% death rate had an immediate domino effect, with, for example, numerous North American States issuing stay-at-home announcements, and with President Donald Trump announcing a national emergency in the USA on March 13. Similar actions followed around the world, with the South African president, Cyril Ramaphosa, declaring a state of disaster on March 15, and later announcing on March 23 a national lockdown beginning on March 26, 2020.

The South African political leadership's decision to declare and enforce one of the world's strictest lockdowns is of particular chronological interest. On March 17, two days after Ramaphosa declared a state of disaster, and a week before the declaration of a strict lockdown on March 23, John P.A. Ioannidis (2020) provided commentary that problematised Ghebreyesus's use of a $3.4 \%$ death rate. In his commentary, Ioannidis went so far as to state the following: "Reported case fatality rates, like the official 3.4\% rate from the World Health Organization, cause horror - and are meaningless." To anyone who was willing to look beyond the WHO's 3.4\% death rate, it was clear that the WHO had been reckless in their estimate of the statistical chance of dying from Covid-19. Even in the popular media, proverbial eyebrows were raised early-on at the uncontextualised statistic: as one reporter put it on March 11,3.4\% "was not a modest estimate" (Belluz 2020). There are numerous reasons why Ghebreyesus's statistic was problematic. For example, there is an important difference between case fatality rates (CFT) and infection fatality rates (IFR), and the WHO had used a particularly badlysourced and unrepresentative CFT; and it is also not a clear-cut matter of determining who dies from Covid-19 versus with it—correlation is not cause.

While appeals to authority may not often be appropriate, the epidemiological and statistical context of Ghebreyesus's use of a 3.4\% death rate does call for consideration of Ioannidis's particular area of undeniable epidemiological expertise. Ioannidis's profile entry in the Stanford University Profiles (2020) speaks for itself, with long lists of impressive academic and administrative appointments; honours and awards; participation on boards, councils, advisory committees, and professional organisations; all of which provides the background for the summary of his present positions: "C.F. Rehnborg Chair in Disease Prevention, Professor of Medicine, of Epidemiology and Population Health, and (by courtesy) of Biomedical Data Science, and of Statistics; coDirector, Meta-Research Innovation Center at Stanford (METRICS)." If there was one expert whose views absolutely should have been included in the decision processes behind lockdowns and pandemic restriction measures, it was that of Ioannidis. 


\section{Pittaway}

However, despite having ample time to contextualise the "meaningless" $3.4 \%$ death rate announced by Ghebreyesus, and to strategise and implement an immediately-nuanced action plan (that would not have shut down the economy) to deal with the spread of the Covid-19 virus in South Africa, the country's political leadership opted instead to declare and enforce a Draconian and paternalistic series of one-size-fits-all lockdown measures. I am absolutely not implying, at any stage in this article, that the South African government should not have reacted decisively to the pandemic, but the heavyhanded nature of the lockdown response does call for scrutiny in light of the analysis that I will offer here. If expert views such as the ones espoused by Ioannidis had been considered by the leadership, they were clearly put aside, and favour was given instead to the worst-case position of the WHO at the time-indeed, Ramaphosa (2020a) referred favourably to the WHO twice in his speech of March 23. In the same speech, Ramaphosa stated the following: “... drastic measures are required to contain the spread of the virus to save lives." In almost all of his subsequent lockdown speeches, Ramaphosa repeatedly stated that the severe lockdown decisions made by the South African government were made "to save lives," despite it being impossible to know at that stage if locking down so severely would save more lives than it would take considering, for example, the crippling and often fatal level of poverty that already existed in the country; levels that would be exacerbated by the economic consequences of the one-size-fits-all lockdown measures. Furthermore, lockdowns may buy a State some time to better understand a situation and slow a pandemic, but if an earlier spike in positive cases is simply delayed until a later stage, legitimate questions can be asked about the extent to which harsh lockdowns add insult to injury.

In his lockdown speeches, Ramaphosa also stated the number of deaths allegedly from the virus, as well as the total number of positive tests. He never added context to the numbers; if he had, it would be clearer to citizens that he was stating the CFR, and not the IFR, with the IFR ultimately being unknown. However, the IFR will always be smaller than the CFR, because, as Ioannidis made clear in his March 17 commentary, "We don't know if we are failing to capture infections by a factor of three or 300." This matters immensely, because the denominator of total positive infections in a society is the denominator that must be used for an accurate picture of the fatality rate of the virus, but it was missing throughout South Africa's lockdowns. At the time of writing in August 2020, one of the most up-to-date models for estimating the general IFR of Covid-19 was detailed in a paper by Silverman, Hupert, and Washburne (2020). The authors estimate that "more than $80 \%$ of individuals with SARS-CoV-2 infections in the US went undetected in March 2020," which drastically lowers the general CFR associated with the virus - this is exactly what Ioannidis was trying to call attention to on March 17, and it is relevant to every country's infection and fatality rates, suggesting that the virus had spread far and wide in the USA before March, which may be relevant for the virus's movement in general. Elsewhere, Silverman and Washburne (2020) write: "The Centers for Disease Control and Prevention currently has a best guess of $0.65 \%$ for the IFR. But current estimates fall anywhere between $0.2 \%$ and $1 \%$." With less than a 1\% IFR, the WHO's initial 3.4\% CFR is revealed for what it is: completely 


\section{Pittaway}

lacking in essential context. This is not just a matter of hindsight-Ioannidis and others had already voiced their concerns before the South African lockdown, and as I have illustrated, it is a relatively straightforward matter of arriving at Ioannidis-style questions about using CFR death rates as a basis for making informed decisions.

The concerns I have raised so far may lead to speculations about extraneous intentions that may have been driving lockdowns around the world. In South Africa, for example, it is unarguably the case that the country's government is in a legitimation crisis: plagued with corruption, and having drained the country's coffers over the course of a quarter century, it is within the realms of possibility that the African National Congress (ANC) welcomed the pandemic as an alibi to do three things. First, to deflect from the real reasons why the country is bankrupt (with corruption and state capture being central factors in this regard). Second, to legitimise government, or, re-stated, to create the public impression that the ruling party is doing something useful by allegedly protecting the public from the virus. Third, to justify the creation of R500bn worth of bailout funds that would re-load the coffers that the ruling party had hitherto largely pillaged - this would constitute, in part, the insult to injury I have already mentioned. While these points may seem overly speculative, they are in keeping with what Naomi Klein (2020) calls "Coronavirus Capitalism": "Governments around the world are busily exploiting the coronavirus crisis to push for no-strings-attached corporate bailouts and regulatory rollbacks." Already, at the time of writing, corruption charges had been laid with regard to the mismanagement of the bailout funds in South Africa.

There are, of course, numerous contextual factors that should be taken into consideration when trying to comprehend a scenario as complex as the one in which Covid-19 lockdowns were imposed. While I contend that all of the aforementioned political moves should be of the utmost interest to anyone concerned for the future of South African democracy in general, I will put them aside as introductory and background points, and turn towards an exploration of what I contend is a potentially coherent explanation for what is otherwise a contentious series of moves made by the South African political leadership in response to the Covid-19 pandemic. This conceptual arena is primarily the precautionary principle, for which I lay a basic theoretical foundation in the second section. In the third section, I relate the theory of section two to some of the contextual factors that were at play in South Africa in order to offer an explanation for some of the decisions made by the South African leadership in response to the pandemic.

In the fourth section of this article, I argue that if the precautionary principle can be used as an addition to the general defence of the Draconian and paternalistic series of decisions made by the South African leadership in response to the Covid-19 pandemic, then in order to remain consistent, the leadership would have to make decisions of similar proportions in light of various other potential threats, some examples of which I briefly discuss. I also argue that if government's focus on saving lives is to be consistent, preventative action in response to phenomena that take alarming numbers of 


\section{Pittaway}

lives annually is also necessary. I conclude in the fifth section, where I argue that, should the South African leadership fail to respond to the mentioned style threats decisively, quickly, and in a manner consistent with its precautionary response to assumed Covid19 threats, then one is left little choice but to defer to an analysis in which the Covid-19 pandemic was seized upon by South Africa's leadership for more reasons than public safety. Whether intentional or not, the South African government's heavy-handedness in managing the country's lockdowns undermined numerous democratic freedoms in a country with a troubled history of repressive state intervention. If the precautionary principle can be appealed to as part of a justification for the State's harsh lockdown measures, then the same principle can be invoked for a variety of possible threats, and perhaps ironically, one of those threats may be heavy-handed and one-size-fits-all lockdowns of questionable suitability in democratic contexts.

\section{The Precautionary Principle: Brief Literature Review}

Academic explorations of the precautionary principle may proceed in painstaking conceptual detail. For example, Daniel Steel's Philosophy and the Precautionary Principle: Science, Evidence, and Environmental Policy (2015) explores abstract terms and phrases such as: a meta-decision rule; maximin and minimax regret; intergenerational impartiality and discounting; the pure time preference; intergenerational impartiality; the argument from inductive risk; uncertainty about uncertainty; science and values; and more. As indicated in the subtitle of his book, the context Steel is interested in is environmental policy. I have referred to Steel and the context of environmental policy to illustrate the point that the ways in which the precautionary principle are employed depend largely on context. Potential environmental problems, for example, may demand concerted action by human beings at some point, but the exact deadline for action may be up for debate considering that a particular ecological problem may not be perceived to translate into imminent disaster. This may explain why concerted efforts to address ecological problems have historically resulted in the setting of goals for the future, such as the United Nation's focus on the year 2030 for the achievement of various sustainable development goals, and the European Union's focus on the same year to cut greenhouse gas emissions (from 1990 levels).

In comparison and contrast to potential environmental problems, threats that are perceived to be more imminent present a different context. While Steel's detailed philosophical consideration of the precautionary principle may yield concepts that are relevant to this context, numerous decisions made during the Covid-19 pandemic have shown that various people in positions of political power can and do make decisions quickly, and in a manner that is far more in keeping with basic and straightforward articulations of the principle. In this regard, Sunstein $(2005,4)$ comments on the precautionary principle in a manner that is far more fitting for what was seen about the decisions made by political leaders in South Africa (discussed in the third section of this article) and elsewhere when faced with a perceived imminent threat: the "Precautionary 


\section{Pittaway}

Principle takes many forms. But in all of them, the animating idea is that regulators should take steps to protect against potential harms, even if causal chains are unclear and even if we do not know that those harms will come to fruition." Sunstein $(2005,13)$ later provides commentary that further simplifies what is denoted by the term: "Avoid steps that will create a risk of harm. Until safety is established, be cautious; do not require unambiguous evidence. In a catchphrase: Better safe than sorry."

Harremoës et al. $(2002,5)$ provide an example of an "early application" of the precautionary principle in the context of public health interventions - considering the Covid-19 pandemic of 2020, the Harremoës et al. example is fitting because it entails an epidemic and a simple response to it. The example is the London cholera epidemic of 1854, and it involves someone who is considered to be a founding figure of modern epidemiology, John Snow. Snow (cited in Harremoës et al. 2002) published a paper a few years earlier in which links between polluted water and cholera had been detailed. "Snow ... recommended removing the handle from the Broad Street water pump in an attempt to stop the cholera epidemic." While Snow's paper had not provided indisputable proof of a causal link between potentially polluted water and cholera, "it was proof enough for Snow to recommend the necessary public health action, where the likely costs of inaction would have been far greater than the possible costs of action (Harremoës et al. 2002)." The authors proceed to point out the following:

The costs of Snow being wrong in getting the pump handle removed would essentially have been angry and inconvenienced citizens who nevertheless wanted cholera stopped. These costs were small in relation to the cost of being wrong in not removing the pump handle, once the evidence of the link between the Broad Street pump water and the cholera was available. His evidence that there seemed to be a link was reliable enough to help make a public policy decision that proved correct: the cholera was being caused by sewagecontaminated water and removing exposure helped to remove the risk. (Harremoës et al. 2002, 5)

Hansen and Tickner (2013) also apply a simplistic version of the precautionary principle that fits the bill for its application by South African political leaders during the Covid19 pandemic. The authors demarcate the context for the application of the principle as one in which "early warnings" exist and "preventative actions" can be taken (Hansen and Tickner 2013, 12). Hansen and Tickner discuss two particularly useful and straightforward concepts relevant for the application of the principle during the Covid19 pandemic: "false negatives" and "false positives." The former involves "instances where early warnings existed but no preventive actions were taken," while the latter involves instances "where government regulation was undertaken based on precaution but later turned out to be unnecessary." The authors focus on four case studies where false positives were at play: "US swine flu, saccharin, food irradiation, and Southern leaf corn blight." Hansen and Tickner defend and favour regulatory action based on a simplified version of the principle: 


\section{Pittaway}

Overall, the analysis shows that fear of false positives is misplaced and should not be a rationale for avoiding precautionary actions where warranted. False positives are few and far between as compared to false negatives and carefully designed precautionary actions can stimulate innovation, even if the risk turns out not to be real or as serious as initially feared. (Hansen and Tickner 2013, 17)

Caroline E. Foster (2011) explores the use of a fairly straight-forward version of the precautionary principle in the context of international courts and tribunals. Part of her focus is on how the use of the principle involves a reframing of the concept of burden of proof. The burden of proof requires that claimants provide proof to support their claims. However, Foster $(2011,18)$ points out that "the precautionary principle is understood to involve a move away from the "primacy of scientific proof'."

The emphasis falls instead on the limitations of scientific prediction, and the need for decision-making that errs on the side of allowing for worst-case scenarios. Under the precautionary principle, the idea that it is better to ascertain the facts before taking action is reversed, and it is recognised that it may be better to act first and then set about ascertaining the facts more closely. While preventive action involves intervention prior to the occurrence of damage in relation to known risks, precaution involves a preparedness by public authorities to intervene in advance in relation to potential, uncertain or hypothetical threats. If the risk is sufficiently serious in character, precaution may posit intervention even where a risk is simply suspected, conjectured, or feared. (Foster 2011, 18)

Foster's commentary provides reasons for understanding why political interventions may be tolerated in the legal arena when the rights of civilians are drastically infringed upon. Clear proof may be lacking to defend claims that a threat is imminent, but the potential imminence and potential severity of a threat are seen as sufficient reasons for taking large steps towards limiting potential harm.

\section{The Precautionary Principle and the African National Congress's Lockdowns}

It would be difficult to argue that the higher levels of lockdown in South Africa were not Draconian and paternalistic in character. On 22 May 2020, Minister of Police, Bheki Cele, gave a media briefing (saps.gov.za 2020) in which he stated that 230000 cases of arrest had been opened for "contraventions that include: liquor-related offences; cigarette-related offences; illegal gatherings ...; failure to confine to place of residence ...; cross-border and inter-provincial movement; business-related and transport-related offences ...; fraudulent or no permits." These so-called "contraventions" were enforced with such stern ardour that at least 11 people were killed by police during the lockdown, with hundreds more being assaulted by police (Haffajee 2020). It is not unreasonable to suggest that South Africa's lockdown was similar to the lockdowns of other early-responding countries in name only. For example, Taiwan's leadership also acted quickly and decisively, but "[r]ather than shuttering its economy for weeks on end in an attempt to slow the virus, Taiwan went another way-after 
quickly closing its borders and banning exports of surgical masks, the government used contact tracing and mobile Sim-tracking to identify and ensure those in quarantine were actually abiding by the rules" (Bremmer 2020).

If one looks at, for example, Sweden's responses to the pandemic-responses that can perhaps best be described as suggestions and guidelines-the South African leadership's responses are clearly among the strictest in the world. Sweden's leadership has come under serious fire in the global media for its laissez-faire response to the pandemic, but it will take years before the bigger picture can be seen in order to make sense of which country's particular pandemic responses will have the best overall results. In this light, the widespread criticism of various countries (for example, the USA) that, so the claim goes, did not act quickly enough may not be based on sufficient evidence, but on sentiment - as already referenced, Silverman et al. (2020) estimate that "more than $80 \%$ of individuals with SARS-CoV-2 infections in the US went undetected in March 2020." The implication is that the virus had spread far and wide much earlier than many advocates of strong lockdowns may care to admit. These complex contextual factors, combined with the variety of approaches that were taken in different countries when responding to the pandemic, and added to a long list of controversial topics (such as the false positives associated with PCR tests), indicate that the lockdown decisions made by governments in response to the Covid-19 virus are not self-evident outcomes of objective data. Executive members of each nation's government considered the particular pandemic circumstances that they deemed to be important and relevant, and decisions were made based on limited epidemiological data in combination with a variety of contingent socio-political and economic factors. These kinds of decisions fall partly into the philosophical category of ethics, and they can be summarised under the umbrella question: What should we do?

The leadership of South Africa's ruling party, the ANC, chose to respond to the partlyethical question of what should be done in response to the pandemic by forcing all nonessential service workers to stay at home, with the exception of trips out for food or medicine. The economic consequences of these actions were severe, with Ramaphosa announcing a R500bn bailout package during phase five of the lockdown. Numerous critics pointed out that the economic fallout caused by the severe lockdown measures could have worse overall health consequences than the direct loss of life allegedly from the virus. Alex Broadbent (2020), for example, pointed out in early April that:

... there are less immediate consequences [to lockdowns]. Economic downturn means more people below the poverty line. After the 2008 financial crisis, five million more children were hungry than otherwise would have been. ... At the bottom of the global pile, recession isn't just a matter of falling property prices and disappointing pensions, it's a matter of life and death. When we lock down, we are making a choice. We are saving the lives of some older people, and causing the deaths of some younger people, especially children, who are most at risk of malnutrition and diseases of poverty. (Broadbent 2020) 


\section{Pittaway}

Note Broadbent's comment: when "we lock down, we are making a choice"-this stands in support of my claim that political leaders' responses to pandemics are not selfevident outcomes of objective data. Rather, the decisions about what should be done fall into the category of ethics. Favouring a heavy-handed lockdown involving, for example, the confinement of people indoors, the banning of outdoor exercise, and the prohibition on the sale of alcohol and cigarettes, was an ethical stance taken by the South African leadership, a stance that received due criticism from health experts such as Glenda Gray. Gray is "a member of the ministerial advisory committee ... a group of scientists tasked with advising the government during the Covid-19 pandemic" (Tsobo 2020), and she went so far as to severely criticise the South African leadership's lockdown regulations. As Lindiwe Tsobo writes, in "an interview with News24, Gray is quoted as criticising the government's lockdown approach as 'unscientific,' and that it seemed as if the government was 'sucking regulations out of their thumb and implementing rubbish'."

Concerns raised by Broadbent, Gray, and other commentators, give some insight into why Sunstein (2005) is particularly weary of the precautionary principle as a guideline for making decisions in any conditions. He writes, "the Precautionary Principle is literally incoherent, and for one reason: There are risks on all sides of social situations. It is therefore paralysing; it forbids the very steps that it requires. Because risks are on all sides, the Precautionary Principle forbids action, inaction, and everything in between" $(2005,4)$. While this concern is certainly relevant to the decisions made by the leadership of the South African government during the Covid-19 pandemic, in that the decisions led to some extremely problematic outcomes (for example, the near standstill of economic activity on which so many people depend for survival), it is still possible to defend the leadership's decisions by invoking the most simplistic version of the precautionary principle. The following hypothetical reasoning, although problematic, illustrates my point: if there is the potential for lockdown to save an unknown but presumably large number of lives, then we should lock down despite the unknown but presumably lower number of lives that might be lost due to other potential consequences.

President Ramaphosa stated in several of his lockdown speeches that the severe actions taken by the authorities in South Africa were "to save lives." For example, and in addition to the example already provided from the speech of March 23, Ramaphosa stated the following on 13 May 2019: "By answering the call to stay at home and stay safe, you, the people of South Africa, have helped us to save many lives." Considering that there was no epidemiological evidence available to support the implied claim that lockdowns save more lives than do other non-lockdown approaches to pandemics like herd immunity or nuanced risk mitigation strategies, or that short-term benefits of locking down outweigh long-term negative consequences of doing so, Ramaphosa's appeal to the saving of lives can be supported by the simplistic context established in the above discussion. It was seen that Sunstein's definition of the principle entails the following: "regulators should take steps to protect against potential harms, even if causal 


\section{Pittaway}

chains are unclear and even if we do not know that those harms will come to fruition." This approach is, of course, problematic, as Sunstein (2005) goes to great lengths to convey, but Ramaphosa's unsubstantiated claim about the saving of lives fits in the context of uncertainty in which the precautionary principle is often called for.

While there is uncertainty about the consequences of both strict lockdowns and less strict ones in times of novel virus pandemics, it was seen in the above section via Foster's comments $(2011,18)$ that in times of uncertainty, the "emphasis falls ... on the limitations of scientific prediction, and the need for decision-making that errs on the side of allowing for worst-case scenarios." Right before Ramaphosa's announcements of the national state of disaster and the ensuing national lockdown, various factors were at play that coalesced into a picture where the Covid-19 pandemic looked as if it might have been something of a worst-case scenario. The Director General of the WHO had declared a $3.4 \%$ case fatality rate-despite this statistic being uncontextualised and problematic (Ioannidis 2020), it was issued by an extremely influential international organisation. Some of the world's leading economic powers, such as the USA and the UK, closed borders and issued stay-at-home appeals to their citizens. Sensationalised media coverage of Northern Italy's flurry of deaths allegedly caused by the virus overwhelmed traditional news channels and social media. It had already been established that people with underlying health conditions, as well as the elderly, stood higher chances of dying with Covid-19 were they to become infected with it, and South Africa has a high prevalence of health problems such as HIV/AIDS, tuberculosis (TB), and diabetes. While these (and other) factors do not lead to the logical conclusion that a one-size-fits-all lockdown of a paternalistic and authoritarian character is the only action that must be taken, it is one of the possible actions that a government could justify taking in response to several unknown variables. Considering all of the unknowns, one may therefore attribute good faith and charity to the reasoning that drove decisionmakers in a hapless state administration faced with a serious public health scare.

While it might be possible to argue that the South African leadership's decision to enforce a heavy-handed lockdown is an instance of a response to what Hansen and Tickner (2013) refer to as a false positive, which (as seen above) involves instances "where government regulation was undertaken based on precaution but later turned out to be unnecessary" (insofar as the Draconian and paternalistic characteristics of the lockdown were far too heavy handed, and simply delayed the inevitable surge of the Covid-19 virus, as seen in the latter quarter of 2020), the same authors do support such potentially unnecessary actions. They do so because "fear of false positives is misplaced and should not be a rationale for avoiding precautionary actions where warranted." The authors favour "carefully designed precautionary actions" that "can stimulate innovation, even if the risk turns out not to be real or as serious as initially feared" (Hansen and Tickner 2013, 17). The hard and fast, one-size-fits-all lockdown was anything but carefully designed, nor did it stimulate much innovation; rather, it was more of a knee-jerk reaction to a perceived risk. The leadership of various other countries clearly did carefully design their precautionary responses, for example Taiwan 


\section{Pittaway}

and Iceland (Hsieh and Child 2020), where economic activity was not crippled by the decisions made by the leadership of the countries, and where citizens' rights and freedoms were largely respected. However, with South Africa's unenviable economic situation being incomparable to Taiwan's or Iceland's, an "act-forcefully-now" approach (as favoured to a large extent by Hansen and Tickner) is clearly one that the South African leadership thought was best for the country. The country's leadership had been exposed to the international Covid-19 media frenzy, and they were likely to have experienced considerable pressure from various national and international organisations to respond to the pandemic, with attention turning to what appeared at the time to be positive examples of countries like China where harder lockdowns seemed to have contained the virus. Given these factors and others like them, as well as the uncertainty surrounding the overall harm that the Covid-19 virus may cause, the South African leadership's response to the virus may be defended as a plausible precautionary response.

\section{Saving Lives: The Precedent set during the Covid-19 Lockdowns}

The problem for the members of the South African leadership is that their decision to severely lock the country down, as directed in part by the most straightforward version of the precautionary principle, has significant implications for governance and accountability. Ramaphosa's use of the phrase "to save lives" in several of his lockdown speeches has set a precedent upon which light can be shed in hindsight of some of the content of the above discussions, and by incorporating another principle geared towards saving lives, namely the principle of prevention. The leadership of South Africa demonstrated during the Covid-19 pandemic that despite an absence of reliable data pertaining to a potential threat, government is willing to apply the precautionary principle when faced with the mere potential of a sizeable threat. To use the phrase offered by Sunstein $(2005,13)$, the South African government has shown that it is willing to operate according to the principle that it is better to be safe than sorry. Various inconveniences caused by government interventions in public and private life and to democracy and the economy in general are demonstrably not overriding factors for the South African leadership when the interventions they decide upon have the potential to save an unknown number of lives. The South African leadership has, to use Foster's phrase (Foster 2011, 18), committed itself to "act[ing] first and then set[ting] about ascertaining the facts more closely" later when faced with a potential threat. Considering this precautionary precedent set by the South African leadership in response to the Covid-19 pandemic, various other potential threats demand instant precautionary action from the government. Here follow some examples.

Climate change is a phenomenon that could cause massive amounts of suffering and death. While a decade or two ago it could have been argued that the threat was not an imminent one, the year 2020 brings humanity to within a decade where substantial decreases in greenhouse gas emissions need to occur quickly if global warming can be capped to a manageable $1.5^{\circ} \mathrm{C}$ temperature increase by 2050. As explained in an IPCC 


\section{Pittaway}

(2018) report, in "model pathways with no or limited overshoot of $1.5^{\circ} \mathrm{C}$, global net anthropogenic $\mathrm{CO} 2$ emissions decline by about $45 \%$ from 2010 levels by $2030 \ldots$ reaching net zero around 2050 ... For limiting global warming to below $2^{\circ} \mathrm{C}$ $\mathrm{CO} 2$ emissions are projected to decline by about $25 \%$ by 2030 in most pathways." This will require government interventions that are comparable in scale to those of pandemicstyle lockdown measures, considering that the measures did indeed achieve a rarely seen nation-wide drop in carbon emissions.

The South African government openly acknowledges the considerably large threat posed by climate change. The following is stated on the environment.gov.za webpage: "Climate change is already a measurable reality posing significant social, economic and environmental risks and challenges globally." Further, it is stated on the same page that water issues associated with climate change are already posing major life-threatening threats:

[w]ater is the primary medium through which the impacts of climate change are being felt in South Africa according to the National Water Resource Strategy. ... Increases in climate variability and climatic extremes are impacting both water quality and availability through changes in rainfall patterns, with more-intense storms, floods and droughts; changes in soil moisture and runoff; and the effects of increasing evaporation and changing temperatures on aquatic systems. South Africa has been experiencing a serious drought since 2015, with associated crop losses, water restrictions, and impacts on food and water security. (environment.gov.za)

A Lancet report (Watts et al. 2019, 1841) makes it explicit that the impacts "of a changing global climate on human health" are severe. The impacts over a wide range of indicators (each of which contains numerous sub-indicators) are listed and described in the report. The main indicator headings are: health and heat; health and extreme weather events; global health trends in climate-sensitive diseases; climate-sensitive infectious diseases; food security; and undernutrition. For the relevant section of the report, the authors conclude that the "indicators presented ... provide evidence of the exposures, vulnerabilities, and impacts of climate change on health. They show worsening exposures and vulnerabilities along a range of temperature and precipitation pathways, with reductions in crop yield potentials, and increases in vectorial capacity for a number of climate-sensitive diseases. These effects are felt most acutely by low-income and middle-income countries across the world" (Watts et al. 2019, 1841).

The data foregrounded in the 2019 Lancet report reinforces the findings of a 2016 U.S. Global Change Research Program (USGCRP 2016) report that makes it clear that climate change could wreak havoc across a range of indicators: human health; temperature-related death and illness; air quality impacts; extreme events; vector-borne diseases; water-related illness; food safety, nutrition, and distribution; and mental health and well-being. Considering the precautionary precedent set by the South African leadership, where the explicit focus was on saving lives, major efforts to reduce the 


\section{Pittaway}

worrying impacts of climate change should be at the top of government's priority list. At the very least, considering the extent to which fossil-fuel usage causes greenhouse gas emissions, that in turn contribute to climate change, government should be expected to immediately drop all attempts to fast-track various energy infrastructure projects as gazetted (during lockdowns) by government on 31 July 2020 (Government Gazette Vol. 661). The gazetted changes to legislation would enable energy companies to bypass the environmental impact assessment process, which could mean the fast-tracking of greenhouse-gas emitting energy projects involving oil, gas, or coal. Such ecologically disastrous legislation is completely out of alignment with the South African government's new commitments to acting precautionarily and to saving lives.

Another example of a potential threat is the digital communications technology known as $5 \mathrm{G}$, and it is another example of something that government should ban if its actions are to remain consistent with the precautionary approach favoured during the Covid-19 lockdowns. Various appeals have been made by medical doctors and scientists regarding the risks to human health posed by the addition of $5 \mathrm{G}$ towers to the already alarming number of electromagnetic frequency (EMF) emitting towers that are scattered over most landscapes inhabited by human beings. One of these appeals was supported by "248 scientists from 42 nations" (emfscientist.org) in 2019, where attention was given in part to the fact that the WHO's International Agency for Research on Cancer (IARC 2011) classified EMF fields as "possibly carcinogenic to humans." While there may be controversy surrounding claims about the safety risks of $5 \mathrm{G}$ technology, the South African leadership's decision during the Covid-19 pandemic (a decision that also involved consideration of an announcement from the WHO) has set a precedent towards applying the precautionary principle when the mere potential for lives to be lost is at play - certainty about the number of lives that might be at stake is demonstrably not required. With cancer taking human lives, and with the mere possibility of links existing between $5 \mathrm{G} \mathrm{EMF}$ and cancer, government should halt the erection of $5 \mathrm{G}$ towers. At the very least, government should immediately abandon its proposed plans to legislate in favour of the construction of $5 \mathrm{G}$ towers on whatever property (private or otherwise) government deems appropriate - see Government Gazette Vol. 661, 22 July 2020. This legislation is another instance of a government stance that is completely out of alignment with the new commitments to acting precautionarily and to saving lives.

The examples of climate change and 5G EMF radiation are two examples out of many potential candidates. Genetically modified organisms, biodiversity loss, and concentrations of political power that may lead to violent dictatorship, are a few more examples of phenomena that may arguably cause the loss of human lives (for reasons that cannot be explored here due to space constraints). While each of the listed examples falls into categories where the proverbial jury is out on whether the potential safety concerns are as serious as some commentators claim they are, the precautionary precedent set by the South African leadership during the Covid-19 pandemic shows that government is willing to intervene based on the mere possibility that lives may be saved by their interventions. Exactly how many lives is irrelevant, because while it is 


\section{Pittaway}

impossible to know for sure who dies from Covid-19 versus with it, the South African leadership nevertheless assumed that the virus does cause death rather than being correlated with it. This is perhaps a precautionary assumption during times of uncertainty, and for the sake of consistency, government would have to assume causation where correlation may be at work in other conditions that involve uncertainty.

Considering that the South African leadership was, for the sake of saving an unknown number of lives, willing to declare a state of emergency, bring the economy of the country to a crashing halt, empower police to act ruthlessly in the enforcement of lockdown rules, and so on, it is not unreasonable to expect of the same government a willingness to act decisively and preventatively to save a known and significant number of lives. Here the focus changes from precaution to prevention, but ultimately for the same purpose: "to save lives." As seen in the above discussions, Foster explains that "preventive action involves intervention prior to the occurrence of damage in relation to known risks." If saving lives regardless of the cost of doing so (as was the case during the Covid-19 pandemic) is to be a consistent government priority, then the South African government should work tirelessly to stop the spread of AID/AIDS and TB in the country.

As listed at avert.org (2020), between 71000 and 72000 people died from AIDS-related issues in 2019. According to the WHO (2019), 63000 to 64000 people died from tuberculosis in 2018. The combined number of deaths is approximately 130000 people. While one might take umbrage with the notion that these deaths are caused by the illnesses versus being correlated with them, the same criticism is entirely relevant to any claim about one's death from Covid-19, which may merely be a death with it rather than from it. Government in South Africa is obviously unconcerned with such a distinction, considering that President Ramaphosa stated in numerous speeches the alleged number of deaths from the virus, for example, on 13 May 2020: "This week, our country reached a sad moment in the progression of the coronavirus pandemic, as we recorded our 219th death from the disease" (Ramaphosa 2020b). One can give him the benefit of the doubt considering the precautionary context, but the same benefit of the doubt would have to be applied to the $130000+$ combined deaths from AIDS-related issues and TB. This known number of deaths is larger in scale by a factor of at least eight-and-a-half when compared to alleged Covid-19 deaths in South Africa (at the time of writing in September 2020, the reported number of deaths allegedly from the virus was 14889 ). For the sake of consistency in the often-stated goal of saving lives, preventative measures should match precautionary ones, and immediate action should be taken by the South African government in health arenas such as HIV/AIDS and TB "to save lives" considering the precedent that was set during the Covid-19 pandemic and lockdowns.

The addition of preventative measures to precautionary ones is something that links to recent commentary by Steven Robins (2020). Robins explores the question of why "ordinary suffering," for example the "slow dyings" that are attributed to HIV/AIDS 


\section{Pittaway}

and TB in South Africa, tend to go unnoticed in comparison to "crises" such as the Covid-19 pandemic: "Why are some crises taken more seriously than others, and how did the coronavirus come to crowd out these other catastrophes in our midst?" Part of his answer involves a reference to something that I have already drawn attention to in the first section of this article, via reference to Klein. Robins writes, "Naomi Klein uses terms such as 'shock doctrine' and 'disaster capitalism' to refer to the ways in which governments and corporations exploit crises for profit and political gain. Clearly, crises are open to many possibilities." Robins (2020) provides further food for thought in response to his question, most of which implies that political responses to the Covid-19 crisis were overblown, and he later turns to the disproportionately low levels of attention that various other crises receive from political leaders. I would like to end on an optimistic note and refer to the potential, highlighted by Robins late in his commentary, for the Covid-19 crisis in South Africa to be used as a springboard for reforms that would allow for the consistent saving of lives, and not just in a time of a perceived crisis. The extract I provide highlights President Ramaphosa's alleged commitment to take immediate action:

President Ramaphosa identified the pandemic as a "turning point" in South Africa. In a televised speech to the nation, Ramaphosa told South Africans that this was a totally unprecedented crisis and that the country would never be the same again. He envisaged a new economy would emerge from the ashes of Covid-19, and announced the country's largest ever rescue package of R500 billion. What this speech also seemed to acknowledge was the need for "radical economic transformation" to address what Covid-19 had laid bare - the extreme racialised inequalities, massive structural unemployment, chronic poverty, inequality and hunger. (https://ifaaza.org/another-pandemic-another-crisis/)

For the sake of consistency, the South African leadership must quickly and effectively address the crises highlighted by Robins (2020), as well as other potentially deadly phenomena discussed earlier in this section, in a precautionary and preventative manner.

\section{Conclusion: Consistency or Contention}

This article's contribution is not in its brief literature review of the precautionary principle, but instead its focus on the precautionary nature of the South African leadership's responses to the Covid-19 pandemic, on why the broad context in which these types of responses matters, and on how the responses demand consistency from the country's leadership. Lockdown responses indicate clearly that when faced with a threat of an unknown proportion, the country's leaders are willing to take precautionary steps towards being safe rather than sorry, even if these steps cripple the economy and impose major restrictions on democratic rights and freedoms. Keeping in mind the fact that it was never known how many lives would or could be saved by South Africa's Draconian and paternalistic lockdown measures, and that it was merely assumed that such measures would save lives, it would be inconsistent for the South African 


\section{Pittaway}

leadership not to act when facing at least two particular scenarios involving similar circumstances where lives might be lost and are being lost.

The first scenario is when the leadership is faced with any phenomenon that could potentially cause the loss of human life. The precedent set during the Covid-19 pandemic by the South African leadership dictates that precautionary action must be taken, even if there is uncertainty about the real threats presented by a phenomenonthe mere potential for the phenomenon to take lives is considered to be sufficient grounds to attempt to curtail, restrict, prevent, or deny the phenomenon. Global warming, 5G towers, genetically modified organisms, biodiversity loss, and concentrations of political power that may lead to dictatorship, are just a few instances where precautionary action should be applied for the purpose of consistent government intervention considering the precautionary precedent that has been set during the Covid19 pandemic. While some of these examples may spark contention and debate about the real threats they pose to human life and well-being, the precautionary precedent is that the leadership of South Africa is willing to be safe rather than sorry.

The second scenario involves any phenomenon involving a known and potentially preventable loss of life, such as in the cases of HIV/AIDS and TB. President Ramaphosa made it clear during his lockdown speeches that government interventions "to save lives" are the top priorities of the political leadership, where the context involved an unknown, and indeed unknowable, number of lives that may or may not be saved. With approximately 130000 AIDS and TB-related deaths in South Africa in 2018, preventative action should be added to precautionary action if the goal of saving lives is to be taken seriously. Should the South African leadership not act in a manner that is consistent with its precautionary responses to the Covid-19 pandemic, which involves actions in favour of being safe rather than sorry when faced with phenomena that: a) have the mere potential to take lives; and b) have a known track record of taking large numbers of lives, then the political leadership of South Africa should be held to account for its severe actions in one context and its lack of intervention in the others. A failure to act consistently in the newly-articulated quest to save lives, combined with a failure to account for overly severe pandemic lockdowns, would constitute grounds for citizens at large to apply the precautionary principle themselves and resist further heavy-handed and one-size-fits-all lockdowns of questionable suitability in democratic contexts.

\section{Acknowledgements}

The author acknowledges the financial support received (while researching and writing this article) from the Institute for Coastal and Marine Research (CMR) at the Nelson Mandela University (NMU). All views and opinions expressed in this article belong to the author, and do not necessarily reflect any official position or policy of the CMR or NMU. 


\section{Pittaway}

\section{References}

Avert.org. 2020. "HIV and AIDS in South Africa." Accessed September 7, 2020. www.avert.org/professionals/hiv-around-world/sub-saharan-africa/southafrica\#ffootnote3_4xfr3wi.

Belluz, J. 2020. "Did the Coronavirus get more Deadly? The Death Rate, Explained." Accessed September 7, 2020. www.vox.com/2020/3/5/21165973/coronavirusdeath-rate-explained.

Bremmer, I. 2020. “The Best Global Responses to Covid-19 Pandemic.” Accessed November 19, 2020. www.time.com/5851633/best-global-responses-covid-19/.

Broadbent, A. 2020. "Lockdown is wrong for Africa." https://mg.co.za/article/202004-08-is-lockdown-wrong-for-africa/.

EMFscientist.org. 2019. "U.N. Environment Programme Urged to Protect Nature and Humankind from Electromagnetic Fields (EMF) 4G/5G antenna densification is escalating health risks - a global crisis." emfscientist.org/EMF_Scientist_Press_Release_22_July_2019.pdf

Environment.gov.za. "South Africa's Second National Climate Change Report." Accessed September 7, 2020.

www.environment.gov.za/otherdocuments/reports/southafricas_secondnational_cli matechange.

Foster, C. 2011. Science and the Precautionary Principle in International Courts and Tribunals. UK: Cambridge University Press.

Government Gazette Vol. 661. 22 July 2020. Available at: https://dearsouthafrica.co.za/wp-content/uploads/2020/07/43537_227_CommDigitalTech.pdf.

Government Gazette Vol. 661. 31 July 2020. Available at: https://dearsouthafrica.co.za/wp-content/uploads/2020/08/43571_317_NationalGovernment\%E2\%80\%93enviro-s.pdf.

Haffajee, F. 2020. "Ramaphosa Calls 11 Lockdown Deaths and 230000 Arrests an Act of 'over-enthusiasm' - really!" www.dailymaverick.co.za/article/2020-06-01ramaphosa-calls-11-lockdown-deaths-and-230000-arrests-an-act-of-overenthusiasm-really/.

Hansen, S. F., and J. A. Tickner. 2013. "The Precautionary Principle and False Alarms-Lessons Learned." In Late Lessons from Early Warnings: Science, Precaution, Innovation. European Environment Agency. EEA Report No. 1. www.eea.europa.eu/publications/late-lessons-2. 
Harremoës, P., D. Gee, M. MacGarvin, A. Stirling, J. Keys, B. Wynne, and S. Guedes Vaz. 2002. The Precautionary Principle in the 20th Century: Late Lessons from Early Warnings. UK and USA: Earthscan.

Hsieh, L., and J. Child. 2020. "What Coronavirus Success of Taiwan and Iceland has in common." theconversation.com/what-coronavirus-success-of-taiwan-andiceland-has-in-common-140455.

IARC. 2011. "IARC Classifies Radiofrequency Electromagnetic Fields As Possibly Carcinogenic to Humans." https://www.iarc.fr/wpcontent/uploads/2018/07/pr208_E.pdf.

Ionnides, J. 2020. "A Fiasco in the Making? As the Coronavirus Pandemic Takes Hold, We Are Making Decisions without Reliable Data." www.statnews.com/2020/03/17/a-fiasco-in-the-making-as-the-coronaviruspandemic-takes-hold-we-are-making-decisions-without-reliable-data/.

IPCC. 2018: "Summary for Policymakers." In Global Warming of $1.5^{\circ} \mathrm{C}$. An IPCC Special Report on the Impacts of Global Warming of $1.5^{\circ} \mathrm{C}$ above Pre-industrial Levels and Related Global Greenhouse Gas Emission Pathways, in the Context of Strengthening the Global Response to the Threat of Climate Change, Sustainable Development and Efforts to Eradicate Poverty. www.ipcc.ch/sr15/\#: :text=Special\%20Report,Global\%20Warming\%20of\%201.5\%20\%C2\%BAC,and\%20efforts\%20to\%20era dicate\%20poverty.

Klein, N. 2020. "Coronavirus Capitalism - and how to Beat it." theintercept.com/2020/03/16/coronavirus-capitalism/.

Ramaphosa, C. 2020a. "President Cyril Ramaphosa: South Africa's Response to Coronavirus Covid-19 pandemic." https://www.gov.za/speeches/president-cyrilramaphosa-south-africas-response-coronavirus-covid-19-pandemic-23-apr-2020.

Ramaphosa, C. 2020b. "President Cyril Ramaphosa: South Africa's Response to Coronavirus Covid-19 pandemic." https://www.gov.za/speeches/president-cyrilramaphosa-south-africas-response-coronavirus-covid-19-pandemic-13-may-2020.

Robins, S. 2020. “Another Pandemic, another Crisis?” https://ifaaza.org/anotherpandemic-another-crisis/.

Saps.gov.za. 2020. "Media Briefing: Minister of Police, General Bheki Cele gives an Update on the Levels of Compliance and Adherence to the Covid-19 Lockdown Regulations in the Country." www.saps.gov.za/newsroom/msspeechdetail.php?nid=25968. 


\section{Pittaway}

Silverman, J., N. Hupert, and A. Washburne. 2020. "Using Influenza Surveillance Networks to Estimate State-specific Prevalence of SARS-CoV-2 in the United States." Science Translational Medicine 12 (554).

https://doi.org/10.1126/scitranslmed.abc1126.

Silverman, J., and A. Washburne. 2020. "How Deadly is the Coronavirus? The True Fatality Rate Is Tricky to Find, but Researchers Are Getting Closer." theconversation.com/how-deadly-is-the-coronavirus-the-true-fatality-rate-istricky-to-find-but-researchers-are-getting-closer141426\#: :text=The\%20Centers\%20for\%20Disease \%20Control,of\%20deaths $\% 20$ by\%20total\%20infections.

Stanford University Profiles. 2020. "John P. A. Ioannidis." https://profiles.stanford.edu/john-ioannidis.

Steel, D. 2015. Philosophy and the Precautionary Principle: Science, Evidence, and Environmental Policy. UK: Cambridge University Press. https://doi.org/10.1017/CBO9781139939652.

Sunstein, C. 2005. Laws of Fear: Beyond the Precautionary Principle. UK: Cambridge University Press. https://doi.org/10.1017/CBO9780511790850.

Tsobo, L. 2020. "Professionals Rally behind Glenda Gray over Lockdown Criticisms." www.businesslive.co.za/bd/national/2020-05-24-professionals-rally-behindglenda-gray-over-lockdown-criticisms/.

USGCRP. 2016. The Impacts of Climate Change on Human Health in the United States: A Scientific Assessment. Washington, DC: U.S. Global Change Research Program. https://doi.org/10.7930/J0R49NQX.

Watts, N. et al. 2019. "The 2019 Report of The Lancet Countdown on Health and Climate Change: Ensuring that the Health of a Child Born Today is not Defined by a Changing Climate." Lancet 2019 (394): 1836-78. https://doi.org/10.1016/S01406736(19)32596-6.

WHO. 2019. "WHO Global TB Report 2019." www.who.int/tb/data/GTBreportCountryProfiles.pdf?ua=1.

WHO. 2020. "WHO Director-General's Opening Remarks at the Media Briefing on Covid-19 - 3 March 2020." https://www.who.int/dg/speeches/detail/who-directorgeneral-s-opening-remarks-at-the-media-briefing-on-covid-19---3-march-2020. 